Erna Prihandiwati

p-ISSN 2621-3184 ; e-ISSN 2621-4032

doi: $10.36387 /$ jifi.v3i2.626

\title{
HUBUNGAN ANTARA WAKTU TUNGGU PELAYANAN RESEP TERHADAP TINGKAT KEPUASAN PASIEN DI PUSKESMAS GAMBUT
}

\author{
Erna Prihandiwati ${ }^{*}$, Normila Hayati, Mochammad Maulidie Alfiannor Saputera, \\ Anna Khumaira Sari \\ Sekolah Tinggi Ilmu Kesehatan ISFI Banjarmasin \\ *: ernaprihandiwati1@gmail.com
}

\begin{abstract}
ABSTRAK
Waktu tunggu pelayanan resep merupakan salah satu pelayanan yang dapat mempengaruhi kepuasan pasien, identik dengan kebosanan, kecemasan, dan stress. Aspek utama yang menjadi pengaruh adalah semakin cepat waktu tunggu pelayanan resep maka pasien akan semakin puas. Dalam hal evaluasi dan peningkatan pelayanan maka perlu diketahui gambaran waktu tunggu pelayanan resep non racikan dan resep racikan, tingkat kepuasan pasien terhadap pelayanan resep dimensi Reliability dan Responsiveness, dan hubungan antara waktu tunggu pelayanan resep terhadap tingkat kepuasan pasien di Puskesmas. Metode penelitian ini bersifat non eksperimental dengan pengambilan data secara prospektif. Penelitian dilaksanakan di Puskesmas Gambut pada bulan Maret 2020. Populasi yang diambil dalam penelitian ini adalah pasien atau keluarga pasien yang menunggu dalam pelayanan resep obat non racikan dan resep racikan. Sampel menggunakan consecutive sampling didapatkan 169 responden. Pengumpulan data menggunakan kuesioner dan lembar observasi. Analisa data menggunakan SPSS 16.0. Hasil penelitian menunjukkan bahwa waktu tunggu pelayanan resep non racikan dan resep racikan keselurahannya memenuhi standar SOP Puskesmas Gambut. Tingkat kepuasan pasien dimensi Reliability dengan persentase 74,06\% berada pada kategori puas. Dimensi Responsiveness dengan persentase 76,33\% berada pada kategori sangat puas. Tidak terdapat hubungan (signifikasi 0,306 > $0,05)$ antara waktu tunggu pelayanan resep terhadap tingkat kepuasan pasien di Puskesmas Gambut.
\end{abstract}

Kata Kunci : Waktu Tunggu Resep, Tingkat Kepuasan, Puskesmas

\section{ABSTRACT}

The waiting time for prescription services is one of the services that can affect patient satisfaction, and identical with boredom, anxiety, and stress. The main aspect that becomes an effect is that the faster the waiting time for prescription services, the patient will be satisfied. In terms of evaluation and service improvement, it is necessary to know the description of the waiting time for nonconcocted prescription services and concocted recipes, the level of patient satisfaction with the reliability and responsiveness dimension of prescription services, and the relationship between waiting time for prescription services to the level of patient satisfaction at Public Health Center. This method of research is non-experimental with prospective data retrieval. The research was conducted in Public Health Center Gambut to March 2020. The population taken in this study are patients or families of patients who await in the service of prescription non- 
Jurnal Insan Farmasi Indonesia, 3(2) Desember 2020 (281-290)

Erna Prihandiwati

p-ISSN 2621-3184 ; e-ISSN 2621-4032

doi: $10.36387 /$ jifi.v3i2.626

concoction drugs and recipe blend. Samples used consecutive sampling is obtained 169 respondents. Data collection using questionnaires and observation sheets. Data analysis using SPSS 16.0. The results showed that the waiting time for the non-blend recipe service and recipes blends as a whole meet the standard SOP Public Health Center Gambut. The level of patient satisfaction on the Reliability dimension with a percentage of $74.06 \%$ is in satisfied category. Responsiveness dimensions with a percentage of $76.33 \%$ are in very satisfied category. There is no (signification $0.306>0.05$ ) relationship between the prescription service waiting time of the patient's satisfaction level in Public Health Center Gambut.

Keywords : Recipe waiting time, satisfaction level, Public health care

\section{PENDAHULUAN}

Puskesmas merupakan unit pelayanan kesehatan tingkat Kabupaten/Kota untuk meningkatkan kesehatan masyarakat ${ }^{1}$. Pelayanan kefarmasian adalah salah satu pelayanan yang ada di puskesmas meliputi pengelolaan sumber daya (SDM, sarana prasarana, sediaan farmasi dan perbekalan kesehatan serta administrasi) dan pelayanan farmasi klinik (penerimaan resep, peracikan obat, penyerahan obat, informasi obat dan pencatatan/penyimpanan resep) dengan memanfaatkan tenaga, dana, prasarana, sarana dan metode tatalaksana yang sesuai dalam upaya mencapai tujuan yang ditetapkan ${ }^{2}$.

Pelayanan pada konsumen merupakan pelayanan yang dapat dipertanggung jawabkan dan berimbang. Dalam konteks ini, pelayanan pada puskesmas hendaknya secara transparan menjelaskan alur pelayanan dan standar apa yang akan dilakukan oleh pelayan medis, sehingga pasien mengetahui pada batasan apa dirinya mendapat pelayanan. Persoalan mutu pelayanan merupakan hal terpenting untuk meningkatkan kepercayaan pada puskesmas, contoh dari segi waktu pelayanan ${ }^{3}$.

Indikator mutu pelayanan terdapat pada 5 dimensi kualitas pelayanan yaitu keandalan (reliability), daya tanggap (responsiveness), jaminan (assurance), empati (empahty) dan berwujud (tangibles $)^{4}$. Dalam penelitian ini peneliti hanya akan mengaitkan dimensi reability dan responsiveness terhadap kepuasan pasien, karena dimensi ini lebih 
Jurnal Insan Farmasi Indonesia, 3(2) Desember 2020 (281-290)

Erna Prihandiwati

p-ISSN 2621-3184 ; e-ISSN 2621-4032

doi: 10.36387/jifi.v3i2.626

mengacu kepada teknis pelayanan kefarmasian yang ada di puskesmas.

Kepuasan pasien merupakan hal yang sangat penting dalam suatu pelayanan di sebuah sarana kesehatan. Seorang pasien apabila merasa puas terhadap suatu pelayanan kesehatan akan kembali lagi berobat ke tempat tersebut. Salah satu standar minimal pelayanan farmasi di puskesmas adalah waktu tunggu. Waktu tunggu adalah waktu yang digunakan pasien untuk mendapatkan pelayanan kesehatan, waktu tunggu identik dengan kebosanan, kecemasan, stres, penderitaan dan menurunkan kualitas hidup serta harapan hidup ${ }^{5}$.

Waktu tunggu pelayanan obat salah satu yang mempengaruhi dalam hal kepuasan pasien. Semakin cepat waktu tunggu pelayanan obat pasien semakin puas dalam hal pelayanan. Dalam hal kecepatan waktu tunggu sebagai Tenaga Kefarmasian tidak bisa mengabaikan kerasionalan resep, meracik obat dan mengemas obat tergesa-gesa, dan memberikan informasi obat tidak lengkap.

Berdasarkan uraian diatas maka perlu dilakukannya penelitian tentang

hubungan antara waktu tunggu pelayanan resep terhadap tingkat kepuasan pasien di Puskesmas Gambut.

\section{METODE PENELITIAN}

Sampel pada penelitian ini menggunakan data Puskesmas Gambut pada bulan OktoberDesember 2019 sebagai acuan sampel yaitu sebanyak 3.651 lembar resep dengan rata-rata 1.217 resep per bulan. Dengan rumus Lwanga dan Lameshow diperoleh sampel minimal 169 sampel.

Alat/instrument yang digunakan adalah lembar kuesioner untuk mengukur kepuasan pasien dan lembar observasi untuk mengetahui waktu pengerjaan resep. Lembar kuesioner yang berisi 4 pertanyaan tertulis meliputi 2 butir soal reliability (kehandalan) dan 2 butir soal responsiveness (ketanggapan) yang sudah teruji validasi dan reliabilitas di Puskesmas Gambut dengan nilai uji validitas 0,88825 dan nilai uji reliabilitas 0,910 .

Tingkat kepuasan diberi skor atau nilai dengan kategori sangat puas diberi skor atau nilai "3", kategori 
Jurnal Insan Farmasi Indonesia, 3(2) Desember 2020 (281-290)

Erna Prihandiwati

p-ISSN 2621-3184 ; e-ISSN 2621-4032

doi: 10.36387/jifi.v3i2.626

puas diberi skor atau nilai "2", dan kategori tidak puas diberi skor atau nilai " 1 ".

Perhitungan persentase (\%) kesesuaian resep.

Untuk melihat hubungan waktu tunggu pelayanan resep dan tingkat kepuasan pasien dilakunan analisis dengan SPSS 16.0. yaitu uji Spearman

a. Persentase (\%) resep yang memenuhi standar: Jumlah resep yang memenuhi standar/Jumlah seluruh resep $\times 100 \%$

b. Persentase (\%) resep yang tidak memenuhi standar: Jumlah resep yang tidak memenuhi standar/Jumlah seluruh resep $\times$ $100 \%$

c. Persentase (\%) rata-rata kepuasan pasien : Jumlah pasien (kategori sangat puas, puas, tidak puas)/Jumlah seluruh pasien $\mathrm{x} 100 \%$

d. Persentase (\%) tingkat kepuasan pada dimensi Reliability dan Responsiveness: Jumlah pasien (kategori sangat puas, puas, tidak puas)/Jumlah seluruh pasien $\mathrm{x} 100 \%$

e. Jumlah skor persentase (\%) pada dimensi Reliability dan Responsiveness: (\% sangat puas x 3$)+(\%$ puas x 2$)+(\%$ tidak puas $\mathrm{x} 1) / 3$

\section{HASIL DAN PEMBAHASAN}

Responden yang dijadikan sampel pasien atau keluarga pasien yang menunggu pelayanan resep yang telah memenuhi kriteria inklusi eksklusi, yaitu berumur 18-65 tahun, bersedia mengisi kuesioner, sehat fisik dan mental, dan yang merasakan Pelayanan Informasi Obat (PIO) secara langsung.

\section{Hasil Waktu Tunggu Pelayanan Resep}

Pelayanan resep di Puskesmas

Gambut menggunakan resep perseorangan dimana pasien datang akan menerima obat sesuai dengan resep yang diserahkan kepada tenaga kefarmasian.

Tabel 1. Jumlah Sampel Berdasarkan Jenis Resep Racikan dan Non Racikan Yang Dilayani di Puskesmas Gambut

\begin{tabular}{|c|c|c|c|}
\hline No & $\begin{array}{l}\text { Jenis } \\
\text { Resep }\end{array}$ & $\begin{array}{c}\text { Jumlah } \\
\text { Resep }\end{array}$ & $\begin{array}{c}\text { Persentase } \\
(\%)\end{array}$ \\
\hline 1. & Racikan & 49 resep & $29 \%$ \\
\hline 2. & $\begin{array}{c}\text { Non } \\
\text { Racikan }\end{array}$ & 120 resep & $71 \%$ \\
\hline & Total & 169 resep & $100 \%$ \\
\hline
\end{tabular}


Jurnal Insan Farmasi Indonesia, 3(2) Desember 2020 (281-290)

Erna Prihandiwati

p-ISSN 2621-3184 ; e-ISSN 2621-4032

doi: $10.36387 /$ jifi.v3i2.626

Berdasarkan Tabel 1. resep non racikan lebih banyak dibandingkan dengan resep racikan. Resep non racikan kebanyakan dari poli umum, sedangkan resep racikan kebanyakan dari poli khusus MTBS (Manajemen Terpadu Bayi Sehat). Resep racikan dari poli MTBS seperti pasien yang mempunyai keluhan batuk pilek, demam, dan diare.

Tabel 2. Persentasi Hasil Waktu Tunggu Pelayanan Resep

\begin{tabular}{cccc}
\hline $\begin{array}{c}\text { Resep } \\
\text { Memenuhi } \\
\text { Standar } \\
\text { SOP } \\
\begin{array}{c}\text { Puskesmas } \\
\text { Gambut }\end{array}\end{array}$ & $\begin{array}{c}\text { Persentasi } \\
\text { Memenuhi } \\
\text { Standar SOP } \\
\text { Puskesmas } \\
\text { Gambut (\%) }\end{array}$ & $\begin{array}{c}\text { Resep } \\
\text { Tidak } \\
\text { Memenuhi } \\
\text { Standar } \\
\text { SOP } \\
\text { Puskesmas } \\
\text { Gambut }\end{array}$ & $\begin{array}{c}\text { Persentasi } \\
\text { Tidak } \\
\text { Memenuhi } \\
\text { Standar } \\
\text { SOP } \\
\text { Puskesmas } \\
\text { Gambut } \\
(\%)\end{array}$ \\
\hline 49 resep & & 0 resep & $0 \%$ \\
120 resep & $100 \%$ & 0 resep & $0 \%$ \\
\hline & Di & Puskesmas & Gambut
\end{tabular}

sebagian resep racikan sudah tersedia dalam bentuk puyer dan disiapkan dalam jumlah banyak seperti puyer batuk pilek, dan diare. Setelah resep obat selesai disiapkan kemudian dilanjutkan dengan penulisan etiket. Penulisan etiket harus benar sesuai dengan nama pasien dan aturan pakai yang tertera pada resep. Di Puskesmas Gambut item obat yang memiliki aturan pakai yang sama hanya menggunakan satu etiket saja dan pengemasannya dijadikan satu. Setelah proses penulisan etiket,

dikemas, dilakukan pengecekan kembali kemudian barulah tenaga kefarmasian menyerahkan obat kepada pasien disertai dengan pemberian informasi obat terkait cara pakai obat, aturan minum obat, dan efek samping obat jika diperlukan. Jika terjadi kekosongan obat maupun ketidak jelasan dalam penulisan resep tenaga kefarmasian melakukan konsultasi kepada dokter penulis resep.

Di Puskesmas Gambut menetapkan sendiri waktu tunggu pelayanan resep berdasarkan SOP No.105/UKP/PKM-GBT/I/2017 tentang Pelayanan Apotek untuk resep non racikan $\leq 20$ menit dan resep obat racikan $\leq 25$ menit $^{6}$, sehingga pada penelitian ini mengacu kepada standar yang diterapkan puskesmas tidak mengacu kepada Kemenkes RI No. 129 tahun 2008 tentang Standar Pelayanan Minimal Rumah Sakit dimana resep non racikan $\leq 30$ menit dan resep racikan $\leq 60$ menit $^{7}$. Waktu tunggu pelayanan resep adalah waktu yang diperlukan pasien untuk menunggu resep obat dari resep dimasukkan ke apotek sampai diserahkan kepada pasien 
Jurnal Insan Farmasi Indonesia, 3(2) Desember 2020 (281-290)

Erna Prihandiwati

p-ISSN 2621-3184 ; e-ISSN 2621-4032

doi: 10.36387/jifi.v3i2.626

dengan disertai informasi mengenai obat tersebut.

Pengumpulan data penelitian dilakukan dengan pengamatan waktu tunggu pelayanan resep. Perhitungan waktu tunggu resep dilakukan saat dari pasien menyerahkan resep ke tenaga kefarmasian sampai pasien menerima penyerahan obat disertai pemberian informasi oleh tenaga kefarmasian. Peneliti menggunakan stopwatch untuk menghitung waktu tunggu pelayanan resep dan lembar observasi untuk mencatat waktu analisa pelayanan resep.

Pelayanan resep dilayani di Puskesmas Gambut oleh 1 Apoteker, 1 Tenaga Teknis Kefarmasian, dan 1 admin. Di karenakan 1 Tenaga Teknis Kefarmasian lainnya lagi ada kegiatan lain. Semua resep memenuhi standar disebabkan oleh beberapa faktor yaitu, ketersediaan stok obat lengkap, penulisan resep rasional, tenaga kefarmasian yang mencukupi, resep yang ditulis dokter tidak terlalu beragam, letak ruangan yang tidak terlalu luas, item obat yang tidak terlalu banyak, tersedianya alat penunjang resep racikan seperti blender, mesin press kertas puyer, dan 
Jurnal Insan Farmasi Indonesia, 3(2) Desember 2020 (281-290)

Erna Prihandiwati

p-ISSN 2621-3184; e-ISSN 2621-4032

doi: $10.36387 /$ jifi.v3i2.626

Hal-hal tersebut juga berpengaruh terhadap kepuasan pasien.

Tabel 3. Tingkat Kepuasan Berdasarkan Rata-Rata Kepuasan Pasien

\begin{tabular}{ccc}
\hline Kategori & Responden & $\begin{array}{c}\text { Persentase } \\
(\%)\end{array}$ \\
\hline Sangat & & \\
Puas $76 \%$ & 15 & $8,9 \%$ \\
$-100 \%$ & & \\
$\begin{array}{l}\text { Puas } 56 \%- \\
\text { kurang dari } \\
76 \%\end{array}$ & 149 & $88,2 \%$ \\
$\begin{array}{c}\text { Tidak Puas } \\
\text { kurang dari } \\
56 \%\end{array}$ & 5 & $2,9 \%$ \\
\hline Pada & penelitian & ini untuk
\end{tabular}

mengukur tingkat kepuasan pasien menggunakan kuesioner yang dibagikan kepada pasien sebagai responden. Kuesioner yang digunakan terdiri dari 4 buah soal, dimana dimensi Reliability sebanyak 2 soal sedangkan dimensi Responsiveness sebanyak 2 soal.

Pada dimensi Reliability dengan kategori sangat puas sebesar $22,78 \%$, puas sebesar $76,63 \%$, dan tidak puas sebesar 0,59\%. Dimensi Responsiveness dengan kategori sangat puas sebesar $30,47 \%$, puas sebesar 68,05\%, dan tidak puas sebesar 1,48\%. Hasil dari 169 responden yang telah mendapatkan pelayanan kefarmasian di Puskesmas Gambut berdasarkan dimensi mutu pelayanan adalah sebagai berikut :

Tabel 4. Tingkat Kepuasan Pasien Pada Dimensi Reliability dan Responsiveness

\begin{tabular}{|c|c|c|c|c|c|c|c|c|c|}
\hline \multirow{3}{*}{ Dimensi } & \multicolumn{8}{|c|}{ Perolehan Skor } & \multirow{3}{*}{$\begin{array}{c}\text { Jlh S } \\
(\%)\end{array}$} \\
\hline & \multicolumn{3}{|c|}{ i Sangat Puas (3) } & \multicolumn{2}{|c|}{ Puas (2) } & \multicolumn{3}{|c|}{$\begin{array}{c}\text { Tidak Puas } \\
\text { (1) }\end{array}$} & \\
\hline & $\mathrm{Jlh}$ & $\%$ & S Jlh & $\%$ & $\mathrm{~S}$ & Jlh & $\%$ & $\mathrm{~S}$ & \\
\hline \multicolumn{10}{|c|}{20} \\
\hline Soal 1 & 36 & $21,30 \%$ & 108133 & $78,70 \%$ & 266 & 0 & $0 \%$ & 0 & $73,77 \%$ \\
\hline Soal 2 & 41 & $24,26 \%$ & 123126 & $74,56 \%$ & 252 & 2 & $1,18 \%$ & 2 & $74,36 \%$ \\
\hline \multicolumn{10}{|l|}{$\mathrm{B}$} \\
\hline Soal 3 & 44 & $26,04 \%$ & 132123 & $72,78 \%$ & 246 & 2 & $1,18 \%$ & 2 & $74,95 \%$ \\
\hline Soal 4 & 59 & $34,91 \%$ & 177107 & $63,31 \%$ & 214 & 3 & $1,78 \%$ & 3 & $77,71 \%$ \\
\hline \multicolumn{10}{|c|}{ Keterangan : } \\
\hline \multicolumn{10}{|c|}{ A : Reliability } \\
\hline \multicolumn{10}{|c|}{ B : Responsiveneness } \\
\hline \multicolumn{10}{|c|}{ S : Skor } \\
\hline \multicolumn{10}{|c|}{ Jlh : Jumlah } \\
\hline
\end{tabular}

Berdasarkan Tabel 4. tingkat kepuasan pasien dimensi Reliability pada pertanyaan soal 1 didapatkan nilai persentase total sebesar $73,77 \%$ jika dikonversi pada pengukuran tingkat kepuasan pasien, maka tingkat kepuasan pasien pada kategori puas. Pada pertanyaan soal 2 didapatkan nilai persentase total sebesar $74,36 \%$ jika dikonversi pada pengukuran tingkat kepuasan pasien, maka tingkat kepuasan pasien pada kategori puas. Dalam penelitian ini pada dimensi Reliability pasien sebagai responden merasakan puas dalam hal kecepatan, ketepatan, dan tidak berbelit-belit saat mendapatkan pelayanan kefarmasian di Puskesmas Gambut.

Tingkat kepuasan pasien dimensi Responsiveness pada pertanyaan soal 3 didapatkan nilai 
Jurnal Insan Farmasi Indonesia, 3(2) Desember 2020 (281-290)

Erna Prihandiwati

p-ISSN 2621-3184 ; e-ISSN 2621-4032

doi: 10.36387/jifi.v3i2.626

persentase total sebesar $74,95 \%$ jika dikonversi pada pengukuran tingkat kepuasan pasien, maka tingkat kepuasan pasien pada kategori puas. Pada pertanyaan soal 4 didapatkan nilai persentase total sebesar $77,71 \%$ jika dikonversi pada pengukuran tingkat kepuasan pasien, maka tingkat kepuasan pasien pada kategori sangat puas. Dalam penelitian ini pada dimensi Responsiveness pasien sebagai responden merasakan puas dalam hal Tenaga Kefarmasian dalam memberikan tindakan sehingga pasien tidak lama menunggu obat disiapkan. Pasien merasakan sangat puas dalam hal pemberian informasi mengenai obat yang diberikan oleh Apoteker di Puskesmas Gambut.

Pada dimensi Reliability masih berada pada kategori puas salah satu faktor yang mempengaruhi sebelum obat diserahkan oleh Apoteker pasien diminta tanda tangan di buku pencatatan kalau obat sudah diserahkan kepada pasien atau keluarga pasien, setelah dilakukan Pelayanan Informasi Obat (PIO) pasien diminta tanda tangan lagi di belakang lembar resep untuk menyatakan kalau sudah diberikan

PIO oleh Apoteker. Hal itulah yang menurut pasien pelayanan yang dilakukan oleh petugas apotek berbeli-belit.

Hubungan Antara Waktu Tunggu Pelayanan Resep Terhadap Tingkat Kepuasan Pasien

Uji normalitas pada penelitian ini menggunakan KolmogorovSmirnov Test didapatkan nilai signifikansi sebesar 0,000, apabila nilai signifikansi $>0,05$ data terdistribusi normal. Hasil uji normalitas ini data tidak terdistribusi normal. Uji homogenitas didapatkan nilai signifikansi sebesar 0,043, apabila nilai signifikansi $>0,05$ distribusi data adalah homogen. Hasil uji homogenitas distribusi data adalah tidak homogen.

Data penelitian tidak terdistribusi normal dan homogen sehingga data termasuk non parametrik, uji korelasi yang digunakan untuk menghubungkan waktu tunggu pelayanan resep terhadap tingkat kepuasan pasien menggunakan uji Spearman. Didapatkan nilai signifikansi 0,353 artinya pada uji Spearman apabila nilai signifikasi $<0,05$ maka dinyatakan terdapat hubungan yang 
Jurnal Insan Farmasi Indonesia, 3(2) Desember 2020 (281-290)

Erna Prihandiwati

p-ISSN 2621-3184 ; e-ISSN 2621-4032

doi: 10.36387/jifi.v3i2.626

bermakna antara dua variabel yang di

pendaftaran dan menunggu

uji yaitu waktu tunggu resep dengan

pemeriksaan sehingga pasien

kepuasan pasien. Ternyata pada

penelitian ini tidak terdapat hubungan

antara waktu tunggu resep dengan

kepuasan pasien karena nilai

signifikansi $>0,05$.

Hasil penelitian ini menyatakan $\mathrm{Ha}$ diterima dan $\mathrm{H}_{0}$ ditolak. Hal ini menunjukkan pelayanan waktu tunggu resep yang sudah sesuai dengan SOP Puskesmas Gambut dimana resep racikan $\leq 25$ menit dan resep non racikan $\leq 20$ menit tidak menjadikan pasien mendapatkan kepuasan secara merata.

Faktor yang memicu ketidak puasan pasien, pasien tidak mengetahui bahwa waktu tunggu pelayanan resep di Puskesmas Gambut sudah sesuai dengan SOP yang diterapkan oleh puskesmas, merasa bosan dan capek karena mengantri berobat di sana sudah dari pagi hari serta belum tersediannya ruang tunggu pelayanan resep yang memadai dan nyaman seperti kursi yang belum mencukupi karena ruang tunggu pelayanan resep tergabung dengan ruang tunggu pelayanan sebagian berdiri menunggu pelayanan resep, tidak tersedianya pendingin ruangan atau kipas angin. Terdapat televisi di ruang tunggu tetapi acara yang ditayangkan seputar kesehatan walaupun disertai dengan gambargambar animasi yang tiap hari selalu tayangan itu terus yang ditayangkan sehingga anak-anak tidak terlalu minat menonton sehingga lebih suka lari-larian yang mengakibatkan perasaan jengkel orang tua karena capek, lelah, dan lagi sakit.

\section{KESIMPULAN}

Hasil waktu tunggu pelayanan resep non racikan dengan sampel 120 lembar resep yang memenuhi standar sebanyak 120 lembar resep dengan persentase $100 \%$. Resep racikan dengan sampel 49 lembar resep yang memenuhi standar sebanyak 49 lembar resep dengan persentase $100 \%$.

Tingkat kepuasan pasien terhadap pelayanan resep dimensi Reliability dengan persentase $74,06 \%$ berada pada kategori puas. Pada dimensi Responsiveness dengan 
Jurnal Insan Farmasi Indonesia, 3(2) Desember 2020 (281-290)

Erna Prihandiwati

p-ISSN 2621-3184 ; e-ISSN 2621-4032

doi: $10.36387 /$ jifi.v3i2.626

persentase $76,33 \%$ berada pada

Puskesmas Di Kabupaten

kategori sangat puas.

Tidak terdapat hubungan (signifikasi 0,353) antara waktu tunggu pelayanan resep terhadap tingkat kepuasan pasien sehingga tidak berlaku semakin cepat waktu tunggu resep yang didapat pasien semakin tinggi rasa kepuasan pada pasien

\section{DAFTAR PUSTAKA}

1. Kementerian

Kesehatan. Peraturan Menteri Kesehatan Republik Indonesia Nomor 75 Tahun 2014. tentang Pusat Kesehatan Masyarakat. Jakarta. Kementerian Kesehatan Republik Indonesia. 2014.

2. Kementerian Kesehatan. Peraturan Menteri Kesehatan Republik Indonesia Nomor 30 Tahun 2014, tentang Standar Pelayanan Kefarmasian Di Puskesmas. Jakarta, Kementerian Kesehatan Republik Indonesia. 2014.

3. Ma'rufi, I., Khoiri, A., Indrayani, R., Prasetyo, H. Kepuasan Masyarakat Terhadap Pelayanan Puskesmas : Kajian Kualitatif Kultur Medis, Standarisasi Mutu, Konsep Puskesmas Dan Relasi Dokter Pasien Di Kabupaten Jember. Jurnal IKESMA. 2015. Vol. 11 No.1:72-89.

4. Parasuraman, V.A. Analisis Hubungan Persepsi Mutu Pelayanan dengan Tingkat Kepuasaan Pasien Balai Pengobatan (BP) Umum Tasikmalaya. Tesis. Universitas Diponegoro. Semarang. 2011.

5. Febriani, N. Pemanfaatan Waktu Tunggu Dengan Edukasi Kesehatan Melalui Smart Phones. Manajemen Keperawatan FIK UI. 2012.

6. Kepala Puskesmas. Pelayanan Apotek Di Puskesmas Gambut. Kabupaten Banjar. 2017

7. Kementerian Kesehatan. Peraturan Menteri Kesehatan Republik Indonesia Nomor 129/Menkes/SK/II/2008, tentang Standar Pelayanan Minimal Rumah Sakit, Jakarta, Kementerian Kesehatan Republik Indonesia. 2008. 